\title{
EFEKTIVITAS PENERAPAN PERATURAN PEMERINTAH NO.23 TAHUN 2018 TERHADAP TINGKAT PERTUMBUHAN WAJIB PAJAK DAN PENERIMAAN PPh FINAL PADA KPP PRATAMA MANADO
}

\author{
Tri Sukma Melati Suci ${ }^{1}$, Herman Karamoy ${ }^{2}$, Sintje Rondonuwu ${ }^{3}$ \\ 1,2,3 Jurusan Akuntansi, Fakuktas Ekonomi dan Bisnis, Universitas Sam Ratulangi, Jl. Kampus Bahu, Manado \\ 95115, Indonesia \\ E-mail : tsmelsucii@gmail.com
}

\begin{abstract}
Government Regulation No. 23 Year 2018 (PP 23/2018) is form of tax reform by government as an effort to encourage voluntary tax compliance. PP 23/2018 published on July 1, 2018. The publishing of PP 23/2018 aims to provide convenience, fairness, and simplification of taxation for SMEs taxpayers by cutting the tax rate to $0.5 \%$ on turnover or gross sales that don't exceed Rp 4,8 billions a year. This study aims to determine the growth of taxpayers registered before and after the regulation has been adopted, effectiveness of SMEs tax revenue based on PP 23/2018, and to explain the contribution of the implementation of PP 23/2018 to the revenue of PPh Article 4 Paragraph (2) in the region of KPP Pratama Manado. This research uses a descriptive method. Study result based on the average growth of taxpayers during the 13 months before and after the application, showed that growth of $0.02 \%$ taxpayers, while the effectiveness of SMEs tax revenue is less effective and the contribution of PPh PP 23/2018 on PPh Article 4 Paragraph (2) for 13 months since the implementation of PP 23/2018 it was $7,04 \%$ with very less criteria. In the future, the government, especially KPP Pratama Manado should be more active in exploring the potential of tax revenue and must continue to conduct direct socialization with a personal approach to the taxpayers.
\end{abstract}

Keywords: Growth; revenue; taxpayers; effective; contribution

\section{PENDAHULUAN}

Penerimaan pajak terus mengalami peningkatan setiap tahunnya, hal ini diimbangi dengan upaya pemerintah yang terus melakukan reformasi di bidang kebijakan dan administrasi. Pajak penghasilan termasuk sumber yang cukup besar dalam penerimaan pajak karena subjeknya adalah semua orang yang memiliki penghasilan sebagaimana disebutkan dalam UU PPh Pasal 1, bahwa Pajak Penghasilan dibebankan kepada Subjek Pajak atas penghasilan yang diterima atau diperolehnya dalam satu tahun pajak. Jumlah UMKM yang setiap tahunnya semakin banyak, memberikan peluang kepada pemerintah untuk meningkatkan penerimaan dari sektor ini. Namun, hal tersebut tidak mudah karena UMKM belum memberikan kontribusinya dalam sektor perpajakan. Ketidakseimbangan kontribusi UMKM tersebut merupakan suatu indikasi bahwa tingkat ketaatan UMKM dalam memenuhi kewajiban perpajakan masih sangat rendah. Menanggapi hal itu maka pemerintah menerbitkan kebijakan baru yaitu menurunkan tarif PPh Final bagi pelaku UMKM dari 1\% menjadi 0,5\%, kebijakan tersebut tertuang dalam Peraturan Pemerintah No. 23 Tahun 2018 tentang pajak penghasilan atas penghasilan dari usaha yang diterima atau diperoleh wajib pajak yang memiliki peredaran bruto tertentu, dan diberlakukan secara efektif pada tanggal 1 Juli 2018.

Tentunya dengan pemberlakuan peraturan baru tersebut diharapkan mampu memberikan kemudahan dan kesederhanaan kepada pelaku UMKM dalam melaksanakan kewajiban perpajakan. KPP Pratama Manado merupakan salah satu kantor pelayanan pajak 
yang telah mengimplementasikan Peraturan Pemerintah No.23 Tahun 2018 ini sejak ditetapkan pada tanggal 1 Juli 2018, dengan diterapkannya peraturan tersebut diharapkan dapat mengurangi beban pajak para pelaku UMKM, serta memberikan kemudahan bagi pelaku UMKM untuk melaksanakan kewajiban perpajakannya karena perhitungan pajak menjadi sederhana yakni $0,5 \%$ dari peredaran bruto/omzet.

\section{TINJAUAN PUSTAKA}

Akuntansi Pajak. Akuntansi Pajak menurut Waluyo (2014:35) yaitu Dalam menetapkan besarnya pajak terutang tetap mendasarkan laporan keuangan yang disusun oleh perusahaan, mengingat tentang perundang-undangan perpajakan terdapat aturan-aturan khusus yang berkaitan dengan akuntansi, yaitu masalah konsep transaksi dan peristiwa keuangan, metode pengukurannya, serta pelaporan yang ditetapkan dengan undang-undang

Pajak. Menurut Soemitro dalam Mardiasmo (2018:3), pajak adalah iuran rakyat kepada kas negara berdasarkan undang-undang (yang dapat dipaksakan) dengan tidak mendapat jasa timbal (kontraprestasi) yang langsung dapat ditunjukkan dan yang digunakan untuk membayar pengeluaran umum.

Fungsi Pajak. Mardiasmo (2018:4), mengatakan ada dua fungsi pajak. Pertama, fungsi anggaran (budgetair) yaitu pajak berfungsi sebagai salah satu sumber dana bagi pemerintah untuk membiayai pengeluaran-pengeluarannya. Kedua, fungsi mengatur (regulerend) yaitu pajak berfungsi sebagai alat untuk mengatur atau melaksanakan kebijaksanaan pemerintah dalam bidang sosial dan ekonomi.

Jenis Pajak. Dalam Resmi (2017:7) terdapat tiga jenis pajak yaitu, pajak menurut golongan terdiri atas pajak langsung dan pajak tidak langsung, pajak menurut sifat terdiri atas pajak subjektif dan pajak objektif, dan pajak menurut lembaga pemungut terdiri atas pajak negara dan pajak daerah.

Sistem Pemungutan Pajak. Menurut Mardiasmo (2018:9) sistem pemungutan pajak terdiri atas: (1) Official Assessment System; (2) Self Assessment System; (3) With Holding System.

Syarat Pemungutan Pajak. Mardiasmo (2018:4) mengatakan bahwa agar tidak menimbulkan hambatan dalam pemungutan pajak, maka kegiatan memungut harus berdasarkan syarat-syarat, diantaranya: (1) syarat keadilan; (2) syarat yuridis; (3) syarat ekonomis; (4) syarat finansial; (5) sistem pemungutan pajak harus sederhana.

Wajib Pajak. Dalam UU No.16 Tahun 2009, wajib pajak adalah orang pribadi atau badan, meliputi pembayar pajak dan pemungut pajak yang mempunyai hak dan kewajiban perpajakan sesuai dengan ketentuan peraturan perundang-undangan perpajakan.

Pajak Penghasilan. Menurut Mardiasmo (2018:153) mengatakan bahwa UU PPh mengatur tentang pengenaan pajak penghasilan terhadap subjek pajak berkenaan dengan penghasilan yang diterima atau diperoleh dalam tahun pajak.

Subjek Pajak Penghasilan. Dalam pasal 2 UU No.36 Tahun 2008, subjek pajak dibedakan menjadi dua yaitu: (1) subjek pajak dalam negeri, yang menjadi subjek pajak dalam negeri antara lain, orang pribadi, badan, dan warisan; (2) subjek pajak luar negeri. Yang tidak termasuk subjek pajak berdasarkan pasal 3 UU No.36 Tahun 2008 yaitu, (1) kantor perwakilan negara asing; (2) pejabat-pejabat perwakilan diplomatik dan konsulat; (3) organisasi internasional; (4) pejabat-pejabat perwakilan organisasi internasional.

Objek Pajak Penghasilan. Dalan pasal 4 ayat (1) UU No.36 Tahun 2008 mendefinisikan bahwa objek pajak penghasilan, yaitu setiap tambahan kemampuan ekonomis yang diterima atau diperoleh wajib pajak, yang berasal dari Indonesia ataupun luar Indonesia, yang dapat digunakan untuk konsumsi atau menambah kekayaan wajib pajak dengan nama dan dalam bentuk apapun. 
Tarif Pajak Penghasilan. Mardiasmo (2018:168) menyatakan bahwa pajak penghasilan terbagi menjadi dua, yaitu (1) wajib pajak orang pribadi dalam negeri, yaitu tarif pajak yang diterapkan atas penghasilan kena pajak bagi wajib pajak orang pribadi dalam negeri; (2) wajib pajak badan dalam negeri dan bentuk usaha tetap, tarif pajak bagi wajib pajak badan dalam negeri dan bentuk usaha tetap diturunkan menjadi $25 \%$ sejak tahun pajak 2010.

PPh Final (Pajak Penghasilan Pasal 4 Ayat 2). UU No.36 Tahun 2008 Pasal 4 Ayat (2) dalam Mardiasmo (2018:309) menyebutkan PPh yang bersifat final dikenakan atas penghasilan berupa bunga deposito, dan tabungan-tabungan lainnya, penghasilan dari transaksi saham dan sekuritas lainnya di bursa efek, penghasilan dari pengalihan harta berupa tanah dan atau bangunan serta penghasilan tertentu lainnya, yang pengenaan pajaknya diatur dalam peraturan pemerintah. Pengenaan PPh yang bersifat final berarti penghasilan yang diterima ataupun diperoleh akan dikenakan $\mathrm{PPh}$ dalam tarif tertentu. PPh yang dikenakan, baik itu dipotong pihak lain maupun yang sudah disetor sendiri, bukanlah pembayaran di muka atas $\mathrm{PPh}$ terutang, melainkan sudah langsung menlunasi PPh terutang untuk penghasilan itu.

Peraturan Pemerintah Nomor 23 Tahun 2018. Peraturan Pemerintah No.23 Tahun 2018 (PP 23/2018) merupakan revisi dari Peraturan Pemerintah No.46 Tahun 2013 yang mengatur tentang pajak penghasilan atas penghasilan dari usaha yang diterima atau diperoleh wajib pajak yang memiliki peredaran bruto tidak lebih dari $\mathrm{Rp} 4,8 \mathrm{M}$ dalam satu tahun pajak, dan mulai diberlakukan secara efektif pada tanggal 1 Juli 2018. Dalam Christian (2019) terdapat pokok-pokok penting yang diatur dalam PP 23/2018, yaitu (1) tarif PPh Final 0,5\% bersifat opsional; (2) tarif PPh Final sesuai ketentuan PP 23/2018 memiliki batas waktu; (3) omset/ peredaran bruto yang dikenakan kepada wajib pajak UMKM yaitu di bawah Rp4,8 Miliar dalam satu tahun; (4) wajib pajak yang tidak bisa mengenakan PPh final sesuai ketentuan PP 23/2018 adalah wajib pajak orang pribadi yang memperoleh penghasilan dari usaha jasa sehubungan dengan pekerjaan bebas, wajib pajak dengan penghasilan yang berasal dari luar negeri yang memiliki pajak terutang atau yang telah dibayar di luar negeri, wajib pajak yang telah dikenakan pajak penghasilan yang bersifat final lainnya, dan wajib pajak yang memperoleh penghasilan yang tidak termasuk sebagai objek pajak

Pertumbuhan Wajib Pajak. Suryani (2019) menyatakan bahwa pertumbuhan wajib pajak adalah nilai terhadap banyaknya wajib pajak yang terdaftar berstatus secara aktif untuk kewajiban perpajakannya di setiap tahunnya.

Efektivitas. Mahmudi (2010:143) menyatakan bahwa efektivitas merupakan hubungan antara keluaran dengan tujuan atau sasaran yang harus dicapai. Untuk mengetahui tingat efektivitas penerimaan PP 23/2018, digunakan rumus:

$$
\text { Efektivitas }=\frac{\text { Realisasi Penerimaan Pajak }}{\text { Target Penerimaan Pajak }} \times 100 \%
$$

Tabel 1. Klasifikasi Pengukuran Efektivitas

\begin{tabular}{cc}
\hline Presentase & Kriteria \\
\hline$>100 \%$ & Sangat Efektif \\
$90-100 \%$ & Efektif \\
$80-90 \%$ & Cukup Efektif \\
$60-80 \%$ & Kurang Efektif \\
$<60 \%$ & Tidak Efektif \\
\hline
\end{tabular}

Sumber: Rochmadika, 2015 
Kontribusi. Menurut Soekanto (2006:269) menyebutkan bahwa kontribusi sebagai bentuk iuran uang atau dana, bantuan tenaga, bantuan pemikiran, bantuan materi, dan segala macam bentuk bantuan/ sumbangan yang kiranya dapat membantu suksesnya kegiata pada suatu forum, perkumpulan dan lain sebagainya. Untuk mengetahui berapa besar kontriubsi PP 23/2018, maka digunakan rumus:

$$
\text { Kontribusi }=\frac{\text { Jumlah penerimaan PPh PP 23/2013 }}{\text { Jumlah penerimaan PPh Pasal } 4 \text { Ayat (2) }} \times 100 \%
$$

Tabel 2. Kriteria Kontribusi

\begin{tabular}{cc}
\hline Presentase & Kriteria \\
\hline$<10 \%$ & Sangat Kurang \\
$10,01-20 \%$ & Kurang \\
$20,01-30 \%$ & Sedang \\
$30,01-40 \%$ & Cukup baik \\
$40,01-50 \%$ & Baik \\
$>50$ & Sangat baik \\
\hline
\end{tabular}

Sumber: Laksmi, 2016

Penelitian Terdahulu. Sunanto (2016) menunjukan bahwa efektivitas penerimaan pajak UMKM berdasarkan PP No. 46 Tahun 2013 pada KPP Pratama Sekayu untuk tahun 2013 kurang efektif, kemudian pada tahun 2014 dan 2015 tidak efektif. Kontribusi penerimaan pajak PP No. 46 Tahun 2013 terhadap penerimaan PPh pasal 4 ayat 2 periode tahun 2013-2015 masih sangat kurang, sedangkan laju pertumbuhan penerimaan pajak PP No. 46 Tahun 2013 periode 2014-2015 mengalami peningkatan, namun hal ini tidak sebanding dengan jumlah wajib pajak yang terdaftar. Tjiali (2015) dalam penelitiannya pada KPP Pratama Bitung, menyatakan bahwa terjadi pertumbuhan sebesar $6,11 \%$ setelah diterapkan PP 46/2013, sedangkan kontribusi yang diberikan oleh PP 46/2013 terhadap total penerimaan PPh pasal 4 ayat 2 selama kurun waktu 26 bulan sejak diterapkannya PP 46/2013 sampai bulan september 2015 yaitu 5,98\% dengan kategori sangat kurang. Hakim dan Nangoi (2015) menyatakan bahwa setelah diterapkannya PP No. 46 Tahun 2013 terjadi penurunan pertumbuhan wajib pajak sebesar $0,23 \%$, sedangkan penerimaan $\mathrm{PPh}$ pasal 4 ayat 2 dari $\mathrm{PPh}$ UMKM selama kurun waktu 17 bulan sejak diterapkannya PP No. 46 Tahun 2013 mengalami fluktuatif dan masih dalam kategori sangat kurang. Prayogi (2014) menyatakan bahwa di KPP Pratama Magelang penerimaan PPh final yang sangat efektif yaitu bulan Juli dengan rasio efektivitas 128,73\% dan hanya ada satu bulan penerimaan PPh final yang efektif yaitu bulan Oktober dengan rasio efektivitas sebesar 92,33\%, sedangkan untuk bulan lainnya rasio efektivitas kurang dari $90 \%$, tingkat efektivitas penerimaan pajak penghasilan final tahun 2013 kurang efektif karena rasio efektivitas hanya mencapai 81,69\%.

\section{METODE PENELITIAN}

Jenis Data. Penelitian ini menggunakan data kualitatif berupa hasil wawancaa tentang profil perusahaan serta hal-hal yang berkaitan dengan PP 23/2018, dan data kuantitatif berupa data pertumbuhan jumlah Wajib Pajak terdaftar sebelum dan setelah penerapan PP 23/18, target dan realisasi penerimaan PP 23/2018 yang merupakan bagian PPh Final Pasal 4 Ayat (2), dan penerimaan PPh Final Pasal 4 Ayat (2) di KPP Pratama Manado yang disajikan dalam bentuk angka.

Sumber data. Sumber data yang digunakan dalam penelitian ini adalah data primer yaitu data yang diperoleh secara langsung berupa wawancara dengan pegawai KPP Pratama 
Manado. Dan data sekunder yaitu data yang diperoleh secara tidak langsung berupa data wajib pajak terdaftar sebelum dan setelah penerapan PP 23/2018 dari tahun 2017-2019 (bulan terakhir, agustus), peneriman $\mathrm{PPh}$ final pasal 4 ayat (2), serta target dan realisasi penerimaan PP 23/2018 dari tahun 2018-2019.

Metode dan Proses Analisis. Penelitian ini menggunakan metode deskriptif kualitatif. Proses analisis data dalam penelitian ini, yaitu: (1) mengumpulkan seluruh data yang dibutuhkan dengan melakukan wawancara dan dokumentasi pada KPP Pratama Manado; (2) seluruh hasil wawancara lalu ditranskripkan. Langkah ini bertujuan untuk memudahkan dalam menganalisa informasi yang didapat dari informan; (3) langkah selanjutnya, memahami dan mengolah data dengan menghitung data yang berbentuk angkaangka. Data yang telah diolah disajikan kedalam format tabel ataupun grafik sehingga mudah untuk dipahami; (4) tahap terakhir adalah penarikan kesimpulan dari analisis yang telah dilakukan dalam tahap-tahap sebelumnya.

\section{HASIL PENELITIAN DAN PEMBAHASAN}

\subsection{Hasil Penelitian}

Program-Program KPP Pratama Manado dalam Memperkenalkan PP No.23

\section{Tahun 2018}

1. Membuat sosialisasi atau pemberitahuan lewat iklan;

2. Kunjungan langsung ke wajib pajak dengan menyampaikan langsung mengenai aturan dalam PP 23/2018 dan penyampaian surat himbauan;

3. Sosialisasi di kantor kepada para pegawai pajak agar dikemudian hari apabila ada pernyataan dari wajib pajak terkait aturan tersebut, para pegawai pajak yang tidak secara langsung ditempatkan pada bidang pengawasan wajib pajak juga dapat memberitahukan kepada wajib pajak ataupun menghimbau langsung terkait peraturan PP 23/2018; dan

4. Sosialisasi di kantor kepada para wajib pajak yang berpotensi PP 23/2018 dengan mengundang beberapa wajib pajak yang terjaring.

Tabel 3. Pertumbuhan Wajib Pajak Sebelum Penerapan PP No.23 Tahun 2018 di KPP Pratama Manado

\begin{tabular}{clrrr}
\hline Tahun & Bulan & $\begin{array}{c}\text { Jumlah WP } \\
\text { Terdaftar }\end{array}$ & $\begin{array}{c}\text { Pertumbuhan Jumlah } \\
\text { WP Terdaftar }\end{array}$ & $\begin{array}{c}\text { Presentase } \\
\text { Pertumbuhan }\end{array}$ \\
\hline 2017 & Juni & 165.299 & & \\
& Juli & 166.159 & 860 & $0,52 \%$ \\
& Agustus & 167.056 & 897 & $0,53 \%$ \\
& September & 167.953 & 915 & $0,54 \%$ \\
& Oktober & 168.995 & 1.042 & $0,62 \%$ \\
& November & 169.927 & 932 & $0,55 \%$ \\
2018 & Desember & 171.102 & 1.175 & $0,69 \%$ \\
& Januari & 171.920 & 818 & $0,47 \%$ \\
& Februari & 173.082 & 1.162 & $0,67 \%$ \\
& Maret & 173.900 & 818 & $0,47 \%$ \\
& April & 174.823 & 923 & $0,53 \%$ \\
& Mei & 175.760 & 937 & $0,63 \%$ \\
& Juni & 176.641 & 881 & $0,50 \%$ \\
& Juli & 177.404 & 763 & $0,43 \%$ \\
\hline
\end{tabular}

Sumber: KPP Pratama Manado 
Sebelum diterapkannya PP 23/2018, pertumbuhan jumlah wajib pajak tertinggi terjadi pada bulan Desember 2017 yakni mencapai 1.175 wajib pajak, sedangkan jumlah pertumbuhan terendah terjadi pada bulan Juli 2018 yakni hanya mencapai 763 wajib pajak.

Tabel 4. Pertumbuhan Wajib Pajak Setelah Penerapan PP No.23 Tahun 2018 di KPP Pratama Manado

\begin{tabular}{clrrr}
\hline Tahun & Bulan & $\begin{array}{c}\text { Jumlah WP } \\
\text { Terdaftar }\end{array}$ & $\begin{array}{c}\text { Pertumbuhan Jumlah } \\
\text { WP } \text { Terdaftar }\end{array}$ & $\begin{array}{c}\text { Presentase } \\
\text { Pertumbuhan }\end{array}$ \\
\hline 2018 & Juli & 177.404 & 798 & $0,44 \%$ \\
& Agustus & 178.202 & 985 & $0,55 \%$ \\
& September & 179.187 & 1.041 & $0,58 \%$ \\
& Oktober & 180.228 & 853 & $0,47 \%$ \\
& November & 181.081 & 714 & $0,39 \%$ \\
& Desember & 181.795 & 818 & $0,44 \%$ \\
& Januari & 182.613 & 922 & $0,50 \%$ \\
& Februari & 183.535 & 1.475 & $0,80 \%$ \\
& Maret & 185.010 & 1.136 & $0,61 \%$ \\
& April & 186.146 & 1.243 & $0,66 \%$ \\
& Mei & 187.389 & 1.070 & $0,57 \%$ \\
& Juni & 188.459 & 1.469 & $0,77 \%$ \\
& Juli & 189.928 & 1.288 & $0,67 \%$ \\
\hline Agustus & 191.216 & Rata-rata & $0,55 \%$ \\
\hline
\end{tabular}

Sumber: KPP Pratama Manado

Setelah diterapkannya PP 23/2018, pertumbuhan jumlah wajib pajak tertinggi terjadi pada bulan Maret 2019 yakni mencapai 1.239 wajib pajak, sedangkan jumlah pertumbuhan terendah terjadi pada bulan Desember 2018 yakni hanya mencapai 714 wajib pajak.

Tabel 5. Target dan Realisasi Penerimaan PP 23/2018 di KPP Pratama Manado

\begin{tabular}{cccrr}
\hline Tahun & $\begin{array}{c}\text { Target Penerimaan } \\
\text { PP 23/2018 }\end{array}$ & $\begin{array}{c}\text { Realisasi Penerimaan } \\
\text { PP 23/2018 }\end{array}$ & $\begin{array}{c}\text { Efektivitas } \\
(\mathbf{\%})\end{array}$ & Kriteria \\
\hline 2018 & 24.516 .380 .998 & 10.693 .519 .206 & 43,61 & Tidak efektif \\
$2019^{*}$ & 21.067 .693 .280 & 14.826 .778 .467 & 70,37 & Kurang efektif \\
\hline
\end{tabular}

Sumber: KPP Pratama Manado

Realisasi penerimaan pajak PP 23/2018 mengalami peningkatan sejak diterbitkannya pada tahun 2018 sampai dengan tahun 2019 (Januari - Agustus). Pada tahun 2018 realisasi penerimaan PP 23/2018 yaitu sebesar Rp10.693.519.206 dari target sebesar Rp24.516.380.998. Sedangkan dari data yang diperoleh sampai bulan Agustus 2019, realisasi penerimaan PP 23/2018 tahun 2019 yaitu sebesar Rp14.826.778.467 dari target sebesar Rp21.067.693.280. 


\begin{tabular}{|c|c|c|c|c|c|}
\hline Tahun & Bulan & $\begin{array}{c}\text { Penerimaan PP } \\
\text { 23/2018 (Rp) }\end{array}$ & $\begin{array}{l}\text { Total Penerimaan PPh } \\
\text { Pasal } 4 \text { Ayat } 2(\mathrm{Rp})\end{array}$ & Penerimaan & Kriteria \\
\hline \multirow{6}{*}{2018} & Juli & 2.281 .986 .834 & 20.549 .450 .696 & 11,10 & Kurang \\
\hline & Agustus & 1.661 .913 .242 & 29.148.937.321 & 5,70 & Sangat Kurang \\
\hline & September & 1.526 .222 .659 & 25.396 .051 .525 & 6 & Sangat Kurang \\
\hline & Oktober & 1.964 .922 .895 & 25.932.326.708 & 7,57 & Sangat Kurang \\
\hline & November & 1.559 .926 .609 & 30.229 .692 .296 & 5,16 & Sangat Kurang \\
\hline & Desember & 1.699 .923 .569 & 36.612 .330 .770 & 4,63 & Sangat Kurang \\
\hline \multirow[t]{8}{*}{2019} & Januari & 1.805 .774 .929 & 28.784.960.998 & 6,27 & Sangat Kurang \\
\hline & Februari & 1.591 .652 .468 & 22.503 .847 .090 & 7,07 & Sangat Kurang \\
\hline & Maret & 2.502 .489 .656 & 33.695 .620 .511 & 7,42 & Sangat Kurang \\
\hline & April & 2.016 .186 .935 & 23.722 .093 .719 & 8,49 & Sangat Kurang \\
\hline & Mei & 1.563 .534 .506 & 29.642 .465 .888 & 5,27 & Sangat Kurang \\
\hline & Juni & 1.558 .001 .739 & 21.282.564.314 & 7,32 & Sangat Kurang \\
\hline & Juli & 1.925 .033 .563 & 23.321.906.133 & 8,25 & Sangat Kurang \\
\hline & Agustus & 1.864.104.671 & 22.275 .364 .512 & 8,36 & Sangat Kurang \\
\hline
\end{tabular}

Sumber: KPP Pratama Manado

Penerimaan PP 23/2018 tertinggi terjadi pada bulan Maret 2019 mencapai Rp2.502.489.656, dan terendah terjadi pada bulan September 2018 sebesar Rp1.526.222.659. Sedangkan penerimaan PPh Pasal 4 Ayat (2) tertinggi terjadi pada bulan Desember 2018 mencapai Rp36.612.330.770, dan terendah terjadi pada bulan Juli 2018 sebesar Rp20.549.450.696.

\subsection{Pembahasan}

Pertumbuhan Wajib Pajak Sebelum dan Setelah Penerapan PP No.23 Tahun 2018. Rata-rata pertumbuhan wajib pajak penerapan PP $23 / 2018$ yaitu sebesar $0,55 \%$, sedangkan rata-rata pertumbuhan wajib pajak setelah penerapan PP 23/2018, yaitu sebesar $0,57 \%$. Secara keseluruhan ditinjau dari rata-rata pertumbuhan jumlah wajib pajak sebelum dan setelah penerapan PP 23/2018 di KPP Pratama Manado, dapat dilihat bahwa terjadi peningkatan pertumbuhan wajib pajak sebesar $0,02 \%$.

Efektivitas Penerimaan PP No.23 Tahun 2018 di KPP Pratama Manado. Pada tahun 2018 penerimaan PP 23/2018yang terealisasi sebesar Rp10.693.519.206 dari target sebesar Rp24.516.380.998 dengan presentase 43,61\% dengan kriteria tidak efektif. Sedangkan pada tahun 2019, tercatat sampai pada bulan Agustus 2019 penerimaan PP 23/2018 yang terealisasi sebesar 14.826.778.467 dari target sebesar 21.067.693.280 dengan presentase $70,37 \%$ dengan kriteria kurang efektif. Hal ini dikarenakan setelah adanya PP 23/2018pertumbuhan wajib pajak sampai dengan bulan Agustus 2019 hanya tumbuh sebesar $0,02 \%$, sedangkan target yang dibebankan oleh pusat lebih besar serta masih kurangnya kesadaran dari wajib pajak UMKM untuk melaksanakan kewajibannya perpajakannya.

Kontribusi Penerimaan PP No.23 Tahun 2018 terhadap Total Penerimaan PPh Pasal 4 Ayat (2) di KPP Pratama Manado. Penerimaan PP 23/2018terhadap total penerimaan PPh Pasal 4 Ayat (2) yang tertinggi terjadi pada bulan Juli 2018 dengan presentase sebesar 11,10\% dengan kriteria kurang. Sedangkan penerimaan PP 23/2018 terhadap penerimaan PPh Pasal 4 Ayat (2) terendah terjadi pada bulan Desember 2018 dengan kontribusi sebesar 4,63\% dengan kriteria sangat kurang, hal ini dikarenakan oleh pengaruh besarnya penerimaan PPh Pasal 4 Ayat (2) secara keseluruhan terhadap PP 23/2018. Rata-rata kontribusi penerimaan PP 23/2018 terhadap total penerimaan PPh Pasal 4 Ayat (2) selama 13 bulan adalah sebesar 6,94\% dengan kriteria sangat kurang. Kurangnya 
kontribusi yang diberikan oleh PP 23/2018 terhadap total penerimaan PPh Final Pasal 4 Ayat (2) dikarenakan kurang efektifnya penerimaan pajak UMKM berdasarkan PP 23/2018 serta adanya kontribusi jumlah penerimaan penghasilan lain dalam PPh Pasal 4 Ayat (2)

\section{KESIMPULAN DAN SARAN}

\subsection{Kesimpulan}

Berdasarkan data-data yang telah diteliti dan diperoleh serta berdasarkan hasil penelitian yang dipaparkan, maka diambil kesimpulan sebagai berikut:

1. Secara keseluruhan ditinjau dari rata-rata pertumbuhan jumlah wajib pajak antara 13 bulan sebelum penerapan dan 13 bulan setelah penerapan PP 23/2018 di KPP Pratama Manado terjadi peningkatan pertumbuhan sebesar 0,02\%;

2. Efektivitas penerimaan pajak UMKM berdasarkan PP 23/2018 KPP Pratama Manado untuk tahun 2018 tidak efektif dengan presentase 43,61, sedangkan pada tahun 2019 terjadi peningkatan presentase yaitu sebesar 70,37\% dengan kategori kurang efektif.

3. Kontribusi yang diberikan oleh PP 23/2018 terhadap penerimaan PPh Pasal 4 Ayat (2) selama kurun waktu 13 bulan sejak diterapkannya PP 23/2018 sampai bulan agustus 2019 mengalami fluktuatif dan masih dalam kategori sangat kurang, yakni 7,04\%.

\subsection{Saran}

Saran yang dapat diberikan dari hasil penelitian ini yang dapat dijadikan sebagai bahan masukan dan perbaikan bagi Direktorat Jenderal Pajak secara khusus KPP Pratama Manado, yakni harus lebih giat dalam menggali potensi penerimaan pajak khususnya penerimaan pajak yang berasal dari sektor UMKM sesuai dengan ketentuan PP No.23 Tahun 2018, serta mempertahankan kinerjanya dalam mengelola penerimaan PP No.23 Tahun 2018 yang masih tergolong baru, sebaiknya terus dilakukan sosialisasi, pembinaan, serta bimbingan agar tujuan dan sasaran dari peraturan ini dapat tercapai dan sampai kepada masyarakat dengan baik khususnya para pelaku UMKM. Dalam melakukan sosialisasi sebaiknya Direktorat Jenderal Pajak melakukan pendekatan personal agar sosialisasi tersebut lebih menjamah kepada Wajib Pajak secara keseluruhan agar wajib pajak terus bertambah dan penerimaan pajak dari sektor UMKM terus meningkat.

\section{DAFTAR PUSTAKA}

Christian, Y.A., Nangoi G.B., \& Budiarso, N.S. (2019). Implikasi Pengenaan Pajak Penghasilan Final Terhadap Penghitungan Pajak Penghasilan Badan Pada PT. Empat Tujuh Abadi Jaya. Going Concern: Jurnal Riset Akuntansi, 14(1), 10-17. https://doi.org/10.32400/gc.14.1.22243.2019

Hakim, F., \& Nangoi, G.B. (2015). Analisis Penerapan PP No. 46 Tahun 2013 Tentang Pajak Penghasilan UMKM Terhadap Tingkat Pertumbuhan Wajib Pajak dan Penerimaan PPh Pasal 4 Ayat (2) Pada KPP Pratama Manado. Jurnal EMBA, 3(1), 787-795. https://ejournal.unsrat.ac.id/index.php/emba/article/view/7553

Laksmi, D.N. (2017). Kontribusi Komponen Pendapatan Asli Daerah Kota Magelang Tahun Anggaran 2006-2015. Jurnal Economia, 6(2), 166-174. http://journal.student.uny.ac.id/ojs/index.php/ekonomi/article/view/6092

Mahmudi. (2010). Analisis Laporan Keuangan Pemerintah Daerah. Yogyakarta: UPP STIM YKPN.

Mardiasmo. (2018). Perpajakan. Edisi Terbaru 2018. Yogyakarta: Andi. 
Peraturan Pemerintah Republik Indonesia Nomor 23 Tahun 2018 Tentang Pajak Penghasilan Atas Penghasilan Dari Usaha yang Diterima atau Diperoleh Wajib Pajak yang Memiliki Peredaran Bruto Tertentu. Jakarta.

Prayogi, E. (2014). Efektivitas Penerimaan Pajak Penghasilan Final Pada KPP Pratama Magelang Tahun 2013. Skripsi. Fakultas Ekonomi Universitas Negeri Yogyakarta. Yogyakarta. https://eprints.uny.ac.id/16875/

Resmi, S. (2017). Perpajakan: Teori \& Kasus. Edisi 10 Buku 1. Jakarta: Salemba Empat. Rochmadika, D., Zahroh Z.A., \& Nila F.N. (2015). Analisis Efektivitas Penerimaan dan Pertumbuhan Pajak Restoran Sebagai Salah Satu Sumber Pendapatan Asli Daerah (PAD). Jurnal Administrasi Bisnis, 18(1), 1-10. http://administrasibisnis.studentjournal.ub.ac.id/index.php/jab/article/view/727

Soekanto, S. (2006). Sosiologi Suatu Pengantar. Jakarta: Raja Grafindo Persada.

Sunanto. (2016). Efektivitas Penerimaan Pajak UMKM Berdasarkan PP No. 46 Tahun 2013 dan Kontribusi Terhadap Penerimaan. Jurnal Online Insan Akuntan, 1(2), 319-340. http://ejournal-binainsani.ac.id/index.php/JOIA/article/view/200

Suryani, W., Maslichah, \& Junaidi. (2019). Pengaruh Pengalihan PP 462013 Menjadi PP 232018 Terhadap Tingkat Pertumbuhan Wajib Pajak UMKM dan Penerimaan PPh Pasal 4 Ayat (2) di KPP Pratama Pasuruan. Jurnal Ilmiah Riset Akuntansi, 8(02), 3241. http://riset.unisma.ac.id/index.php/jra/article/view/2371

Tjiali, W. (2015). Analisis Penerapan Peraturan Pemerintah Nomor 46 Tahun 2013 Terhadap Pertumbuhan Jumlah Wajib Pajak Dan Penerimaan PPh Pasal 4 Ayat (2) Pada KPP Pratama Bitung. Jurnal EMBA, 3(4), 369-376. https://ejournal.unsrat.ac.id/index.php/emba/article/view/10894/10484

Undang-Undang Republik Indonesia Nomor 16 Tahun 2009 tentang Perubahan Keempat Aas Undang-Undang Nomor 6 Tahun 1983 tentang Ketentuan Umum dan Tata Cara Perpajakan. Jakarta.

Undang-Undang Republik Indoensia Nomor 36 Tahun 2008 tentang Perubahan Keempat Atas Undang-Undang Nomor 7 Tahun 1983 tentang Pajak Penghasilan. Jakarta.

Waluyo. (2014). Perpajakan Indonesia. Jakarta: Salemba Empat. 